\title{
Action Research as Perceived by Student-Teachers in the Field Training Program at Hashemite University / Jordan
}

\author{
Dr. Sadeq Hassan Al-Shudaifat ${ }^{1}$ \\ ${ }^{1}$ Associate professor, Faculty of Educational Sciences, The Hashemite University, Jordan \\ Correspondence: Sadeq H. Al-Shudaifat, Faculty of Educational Sciences, The Hashemite University, P.O BOX \\ 330127, Zarqa 13133, Jordan.
}

Received: December 25, 2019

Accepted: February 9, 2020

Online Published: February 18, 2020

doi:10.5430/ijhe.v9n3p55

URL: https://doi.org/10.5430/ijhe.v9n3p55

\begin{abstract}
Field Training plays a key role in narrowing the gap between theory and practice in the preparation of teachers. University professors and in-service teachers who work in cooperative schools coordinate their efforts to help student-teachers at the Hashemite University link teaching theories to practice.

Student-teachers, sometimes, find themselves isolated from theories learned at the universities and feel the gap between theory and practice. As a result, they tend to use traditional teaching methods in the same way they were taught in the past.

One of the important requirements of the Field Training Program is asking student-teachers to do action research to clarify issues they face during training. Student-teachers face different problems related to action research: selecting issues, preparing, modeling, implementing, and evaluating the results of the research. Therefore, this study attempts at investigating the student-teachers' weakness in carrying out Action Research from the students' own perspective.

To achieve the study objectives, the researcher administered a test on (47) student-teachers, and interviewed (6) others.

The majority of responses conveyed that student-teachers know how to design action research theoretically but they lack the ability and necessary skills to put this into practice. Based on these findings, this research concludes with some suggestions and recommendations to solve the problem.
\end{abstract}

Keywords: action research, field training, practicum, field experience, student-teaching, Student-teachers, Jordan

\section{Introduction}

Field Training is the backbone of the process of preparing teachers. The importance of Field Training is linked to the goals a college of education seeks to achieve which are narrowing the gap between theory and practice, and the compatibility, to certain degree, with the trends in education in the process of teacher preparation and training. Gaining knowledge related to concepts, principles and theories is not an adequate indicator to students' success in the teaching profession. Therefore, Field Training comes to make sure that the application of knowledge, concepts, principles and theories in a practical way is done correctly.

Many studies stressed the importance of Field Training (Al Otaibi 2016, Al Bosaidi et el, 2018, Haron, 2005, Al Qaod 2012, Husein et al, 2019) and they recommended frameworks that help supervisors and students during the field training process.

Zaitoun \& Obaidat (1984) found that $78.2 \%$ of respondents believed that field training education helped them in performing most of teaching requirements in terms of: setting instructional objectives, determining content, selecting teaching resources and implementing the appropriate evaluation. In addition, there was a significant correlation between students' actual practical skills and their university GPA, and that there was a significant correlation between the theoretical aspect and the applied aspect of field training. Abu Numra (2002) noted that students had positive attitudes towards field training program, and that there was no difference between students' attitudes attributed to the college or gender. The researcher recommended the provision of financial incentives for cooperative teachers and principals of schools, and the preparation of short courses for cooperative teachers to develop their professional competencies to undertake tasks and responsibilities in the program of field training. 
Khawaldeh (2003) recommended the need to train students-teachers in the field training program on the performance of competencies related to teaching of Aqyda, Hadaith, and Fiqh, and other related planning and evaluating skills, and the need to provide references and special teaching materials of Islamic education.

Abu Numra's (2005) found out that there were significant differences in the views of student- teachers in the degree of achievement of program goals, attributed to gender, in the areas of planning programs and in favor of females, and the process of educational supervision in favor of males. Meanwhile, the study did not show differences in other areas of study. Moreover, the presence of statistically significant differences was attributed to the university. The researcher recommended developing joint meetings between officials of the field training program in colleges of Education in private universities to exchange views, and a meeting of educational supervisors to discuss the recent trends in the process of educational supervision. Finally, the study recommended providing incentives for the cooperative parties involved in the field training program.

\subsection{The College of Educational Sciences at the Hashemite University and Field training}

The Hashemite University is a public university in Jordan. It is located in the governorate of Zarqa. The university started teaching in 1995 with a small number of students. Currently, the university has 13 faculties with more than 20 thousand students. The percentage of female students exceeds 65\%. The university was established to achieve distinction in community services, scientific research and discovery and in global cooperation, openness and understanding. It has actually achieved distinction in many of these arias during its relatively short history. It has won several recognition prizes for community service and research efforts among which is the Golizano Health Leadership Award in 2018 and the Emirate Gold Award for Energy in 2017 as well as Prince Al Hasan Award for Scientific Distinction in 2017. The university stands as a model for achieving independence Financial Resources as revenues of its own projects. In this regard, it is the only government university in Jordan that doesn't depend on Government financial support and does not work under budget deficit.

The Hashemite University has around 1200 foreign students from 30 different nationalities. Since establishment, it has graduated more than 73 thousand students in various majors ( The Hashemite University Publication).

The Faculty of Educational Sciences at the Hashemite University adopted sophisticated programs in all its curricula, including field training for the classroom teacher major, which stems from the philosophy of teacher preparation for teaching all school subjects for the first, second and third grades. Student-teachers spend twelve credit-hours $\mathrm{n}$ cooperating schools, whether governmental or private, throughout the entire semester in the last year of undergraduate study.

Field Training at the College of Educational Sciences consists of four stages. Each stage has its objectives and activities, and a special mechanism related to its implementation. Stages include: the initial phase, where the student-teacher is introduced to the different stages of the field training. During this stage, the student-teacher fills special forms related to the field training. The second phase is an observation one, where a student-teacher is required to attend a number of classes for qualified in-service teachers during a period of two weeks. The stage of micro teaching, where a student-teacher is given an opportunity to apply teaching skills, and is required to achieve one or two objectives during a specific time period under the supervision of the in-service teacher, comes in third. During this phase other student-teachers are required to attend the micro teaching practice. Finally comes the Macro Teaching as a conclusion to the training program and it lasts for twelve weeks. During this phase, the student-teacher, in coordination with the cooperative teacher, teaches regular daily classroom. The cooperative teacher is held responsible for the field training of the student-teacher to make sure that consciousness and awareness of all aspects related to training in the field are fulfilled.

The Faculty of Educational Sciences at the Hashemite University designated a special office for the field training program (Hashemite University, 2006) to supervise and develop all issues related to the field training program. As well, The Faculty of Education adopted the competencies approach in field training process.

\subsection{Field Training and the Competencies Approach}

Using the Competencies approach, the student-teacher is perceived as a professional who has the competencies or skills needed in the teaching profession which, if practiced, could lead to observable and measurable outcomes that can be noticed in students' performance (Brookes \& Sikes, 1997; Squires, 1999). A training program including both competencies and skills is needed for the student-teacher to become a qualified teacher, and to carry out learning tasks in the future. It also trains the student-teacher in accordance with a pre-configured list of competencies and skills needed by the teacher which covers aspects of preparation and planning for teaching, competencies and skills associated with the different methods of teaching, classroom management, the use of teaching resources, assessment 
of student learning in its various forms and the ethics of the teaching profession as well as action research (Schmieder, A. 1973). The skills and competencies required for the teaching profession, although might vary from one teaching environment to another or from one cultural environment to another, are almost internationally the same in the that they all include preparation to teach, actual in-class teaching and assessment competencies. In our department, the major competences fall into the three main categories mentioned here with special focus on preparing our student-teachers to skillfully manipulate technology and on-line teaching techniques and use them professionally in their teaching practices as well as to master modern student-based teaching methods to the country move from the traditional teaching strategies that, for ages, negatively affected Arab and Middle astern education systems (Nasser, 2018).

Student-teachers in the Field Training phase are required to perform a group of activities and tasks. These activities and tasks include:

1) Preparation of a semester plan for each of the subjects being taught.

2) Preparation of daily lesson plans, and the production of suitable teaching aids that are used in these lessons.

3) Participation in at least (5) extra-curricular activities in the school which the student selects.

4) Preparation of a project during field training which falls under the Action Research category.

The student-teacher is to conduct research in one of the fields that are the focus of his/her attention and are viewed as problems in need for immediate solutions. The student researcher should also perform the following five steps as mentioned by Hayder (2004), which are:

1) Identify a research problem and formulate a research question. During this step, the researcher selects a priority problem requiring resolution, which is formulated in the form of a research question.

2) Gain adequate knowledge on the issue under study through careful review of existing literature.

3) Prepare work plan and select research tools through the careful design of procedures that will be carried out during the research process. These procedures should be both realistic and adequate in terms of the issue under study. Among the tools that may be used, there are: Observation, Interviews, Surveys and Document Analysis.

4) Carry out the previously designed procedures which include: data collection, organization, analysis and explanation.

5) Writing the research report which consists of: the title, an abstract, an introduction discussing the theoretical background and reviewing literature, objectives, discussion and recommendations, references and appendices.

The academic advisor should supervise students' work step by step during the preparation of the research. It should be noted here that the student - advisor ratio is 12: 1 (i.e. each 12 students are accounted for in the advisor's work load as equaling 3 credited hours). That ratio was then altered to 18-1. Most recently, the university is considering the reduction of this ratio to equal the one used before due to the efforts performed by advisors in supervising students using numerous methods which are summarized as follows:

1) Group meetings: the academic advisor meets with trainee students in groups at the university after each phase in the training process to follow up the application of the required tasks as well as meet with student groups in schools.

2) Individual Meetings: the academic advisor meets with each trainee student individually at the school prior to his/her classroom visit to discuss the student's lesson plan and assess his/her readiness to deliver proper instruction. Post class meetings are held to discuss lesson activities. Student's points of strength are reinforced where as his/her points of weakness are revealed for proper remedy.

3) Guided observation: academic advisors participate while trainee students observe cooperate supervisors, or one another, and after class hold meetings to discuss lesson activities and direct them towards adequate teaching methods.

4) Exchanging experience between trainee students: exchanging experience takes place in the partial application phase while attending classes of cooperate supervisors or other fellow students.

5) Follow-up action research with the students step by step. 
6) Discussing with students primary and secondary notes they provided in the observation card form about the instructional performance of cooperate supervisors and other fellow students in class.

\subsection{Assessing Students' Skills in Field Training}

The evaluation of Field Training students aims at diagnosing points of strengths and weakness related to different teaching skills. It also aims at helping students identify their areas of strength and weakness. It further seeks to help students by reinforcing strong points and finding appropriate methods and remedies to resolve weaknesses. It also aims at explaining the way in which skills, which are considered a crucial component of the students' professional preparation while studying at the faculty of educational sciences, are applied. The evaluation process is articulated in the form of the following standards:

1) An evaluation conducted by the academic advisor through a number of field visits (at least four visits), in order to assess the trainee students' performance and their curricular and extra-curricular activities, by filling a report on each visit using the designated card form.

2) An evaluation conducted by the cooperating school principle and supervisor using a report form prepared by both on each trainee student at the end of training period containing details about students' discipline, behavior and commitment in terms of attendance. This evaluation is handed over discretely at the end of each semester to the Assistant Dean for Field Training Affairs' office.

3) An evaluation conducted by the student-teacher himself/herself of other fellow student-teachers applying a certain lesson during the partial application phase, which is regarded as part of the educational activities that the student assembles in a field training file in accordance with a designated form prepared for that specific purpose.

4) Production of a project or action research by the end of the training process.

5) Students' reports on positive and negative aspects of the training process (Faculty of Educational Sciences, 2006).

The major concern of this research paper is to investigate the effectiveness of one major component of the student-teachers preparation program at the Hashemite University, namely the action research requirement of the field training course. The distribution of students' grades related to the Field Training course according to Article (9) of the Field Training manual (Hashemite University, 2006) designates 15\% of the total students' grade to Action Research. The question that presents itself here is: Does the Faculty of Educational sciences at the Hashemite University achieve its goals of training students on action research? Although some might say that a minor requirement of the course is only assigned to action research which is by itself is just a minor component of the Field Training course is probably not much significant for research effort, the researcher believes that action research as a skill is very important for teachers in general. It is not just a skill that the teachers need to perform, it is rather a tool that they should skillfully utilize to measure up their teaching practice, students' learning and the effectiveness of the teaching-learning environment (O'Connor et el, 2006). The research results are expected to explicitly show that our student-teachers are not properly qualified in carrying out professional action research projects; a fact that can constitute a major hindrance to their future teaching career.

Shatat (1995) points out that educational research courses provided by different programs at the faculties of educational sciences do not achieve their main goals of training perspective teachers on conducting field research, which may contribute to the resolution of educational problems that face them in classrooms, as a result of viewing research courses as being theoretical in nature and not having the ability to train students in the practical aspects of research skills. Hence, he demands the training of prospective teachers on action research skills so that he/she can be able to resolve possible problems that may face him/her. Teachers' professional preparation is not fully achieved unless the teacher acquires efficiencies related to preparing Action Research studies that enable him/her from keeping up to date and allowing him/her opportunities of continuing professional growth.

Sheikh (1998) indicates that what leads to strengthening the link between educational research and educational decision making is training teachers on scientific thinking and action research and work on their introduction to schools.

Action research is defined by Hewat as "a process that allows for teachers to reflect on their own practices, and enables them to monitor student learning". Sakor, on the other hand, defines it as a "spiral process consisting of three steps: planning, taking action, and seeking facts about the procedure that has been taken". 
Finally, due to the increasing importance of field training, it was regarded, by the ministry of education in Jordan, as being part of teacher's pre service preparation programs in the Jordanian universities (Ministry of Education, 1988).

\subsection{Study Problem and Questions}

While observing student teachers in the field, Class-Teacher major ( student-teachers majoring to work as teachers of early elementary classes - grades 1-3), the researcher found that students face problems when attempting to write action research. Each student is required to conduct an action research that will be included in his/her field training file. Educational literature is formulated in an academic language that may be difficult to understand. Thus, many students avoid reading it. Action research formed a possible resolution to this problem. The ministry of education in its National Standards Conference for the Professional Development of Teachers (2006) regarded Action Research to be one of the standards of self-development for teachers. However, the ministry did not provide a comprehensive conception of Action Research skills. In addition, field training students may exhibit an acceptable understanding of Action Research theory, but when asked to conduct one, many fail to do so. This indicates a gap between theory and practice although educational literature emphasized the necessity for integrating both (Swedy, 1991; Mustafa, 1998; Diab, 1999; albangaly \& Mourad, 2003, and Hindi, 2006).

The study tried to address the problem through the following main question: Does the Faculty of Educational sciences at the Hashemite University achieve its goals of training students on action research? To be more specific, the following sub skills are going to be investigated: action research knowledge skill, action research problem definition skill, action research hypothesis formulation skill, action research data collection skill, action research data analysis skill and action research result extraction skill and to what extent does that reflect on their overall achievement in their specialization.

This question divided to the following sub-questions:

1. To what extent are student-teachers at The Hashemite University are aware of action research and its importance?

2. Is there a statistically significant correlation at $(\alpha=.05)$ between the student-teachers' awareness of action research importance and their accumulated average in their major (specialization) at the Hashemite University?

\section{Method and Procedures}

This study used the Bekheet test in his thesis - Designing a Training Program and Exploring its Effect on Action Research Skills Development in Social Studies Teachers (2009) which includes (50) questions. After a referral process, (30) questions were found appropriate to this research needs.

\subsection{Statistical Processing:}

To answer the first question, means and standard deviations related to the level of Action Research skills knowledge of student-teacher at the Hashemite University were calculated. To answer the second question, Pearson correlation equivalent was used.

\section{Results and Discussion:}

\subsection{Results Related to the First Question:}

To what extent are student-teachers at The Hashemite University are aware of action research and its importance Six Action Research special skills were investigated. 
Table 1. Means and SD connected to student-teachers' awareness of action research and its importance for teaching.

\begin{tabular}{|c|c|c|c|}
\hline Item No. & Item & Mean & $S D$ \\
\hline 1. & $\begin{array}{l}\text { Action Research is defined as a research conducted by a } \\
\text { single teacher or group of teachers for the purpose of: }\end{array}$ & 2.6809 & 1.23546 \\
\hline 2. & Action Research focuses on: & 2.4681 & .88098 \\
\hline 3. & Action Research is classified as: & 2.5106 & .71846 \\
\hline 4. & The purpose of Action Research is: & 3.106 & 1.107 \\
\hline 5. & The fundamental role of a researcher in Action Research is: & 2.6809 & .83683 \\
\hline 6. & One of the qualities of Action Research researcher is: & 2.7021 & .99815 \\
\hline 7. & One of the following does not limit Action Researches: & 2.7660 & .88986 \\
\hline 8. & The importance of Action Research stems from being: & 3.0213 & 1.09325 \\
\hline 9. & A good Action Research plan is characterized by: & 3.0851 & 1.01788 \\
\hline 10. & One of the features of moral practice in Action Research is: & 2.744 & .966 \\
\hline 11. & Action Research is based on: & 2.531 & 1.195 \\
\hline 12. & The process of Action Research depends on: & 2.127 & .969 \\
\hline
\end{tabular}

As indicated in table (1), item (4) scored the highest mean, $\mu=3.106$, which may be attributed to the fact that most student-teachers know the purpose of Action Research as most students enroll in an obligatory course of Educational Research and Statistical Methods. A confirmation of this result appears in one of the female students answers. She states: "yes we've studied a lot about Action Research...theoretically. I wish I had the opportunity to apply that knowledge practically".

In previous academic plans, there were two obligatory courses related to research. They were "Introduction to Educational and Psychological Research" and "Introduction to Educational Statistics". Therefore, the old study plan might have been more feasible in giving students enough practice in doing action research.

Item (12) scored the lowest mean, $\mu=2.12$, in the epistemological domain where the process of Action Research depends mainly on intended observation. This indicated that students did not have the opportunity to carry out this procedure practically, and that they were only satisfied with the theoretical part of it.

Table 2. Means and SD connected to defining action research problem skill

\begin{tabular}{cccc}
\hline Item No. & Item & Mean & SD \\
\hline .13 & $\begin{array}{c}\text { One of the standards of selecting an Action Research problem is } \\
\text { that the problem must be: }\end{array}$ & 1.808 & .824 \\
.14 & A research problem in Action Research is specified in light of: & 2.914 & .951 \\
.15 & $\quad \begin{array}{l}\text { Stating an Action Research problem requires: } \\
.16\end{array}$ & 2.489 & 1.158 \\
& Action Research question may be formulated in a way that & 2.531 & 1.100 \\
& $\quad \begin{array}{l}\text { points to: }\end{array}$
\end{tabular}

Table (2) indicates that item (14) scored the highest mean. $\mu=2.91$, which points out that student-teachers know that Action Research problem is specified in light of the existing educational literature which, in turns, requires intensive research so that students can determine the point to which educational research in this particular issue has reached. This also indicates that student-teachers are well aware of the importance of research in the educational literature.

One student stated: "I enrolled in an Introduction to Educational Research in my first university year but did not understand much. In my fourth year, I enrolled in a second course and gained a lot of knowledge on Action research". 
Table 3. Means and SD connected to formulating action research hypotheses skill

\begin{tabular}{clcc}
\hline Item No. & \multicolumn{1}{c}{ Item } & Mean & SD \\
\hline .17 & When formulating Action Research hypothesis, it must be: & 3.595 & 4.509 \\
.18 & $\begin{array}{l}\text { Which one of the following is wrong in relation to research } \\
\text { hypothesis: }\end{array}$ & 2.617 & 1.152 \\
.19 & $\begin{array}{l}\text { The research hypothesis must not be: } \\
\text { The }\end{array}$ & 2.617 & 1.225 \\
\hline
\end{tabular}

In table (3), item (17) scored the highest, $\mu=3.59$, which indicates that student- teachers understand that Action Research hypothesis is a temporary one that is tested, and can either be accepted or refused.

One student stated: "courses of statistics are all about memorization... if only some parts of these courses were practical; it would be more beneficial to students. Such courses should have their own laps, and be assigned at least one credited hour".

Table 4. Means and SD connected to action research data collection skill

\begin{tabular}{cccc}
\hline Item No. & Item & Mean & SD \\
\hline .20 & When designing Action Research, it needs: & 2.489 & .929 \\
.21 & Which one of the following processes reinforces data collection skill: & 2.872 & .991 \\
.22 & Data collection skill in Action Research is based on: & 2.659 & .961 \\
.23 & The type of data collected by researcher depends on: & 2.063 & .894 \\
.24 & One of the tools that depend on direct interaction between the & 2.446 & .879 \\
.25 & One of the techniques of reviewing previous literature in Action & 2.468 & 1.139 \\
.26 & Revising existing literature relating to Action Research comes after: & 1.680 & .934 \\
\hline
\end{tabular}

In table (4), item (21) scored the highest mean, $\mu=2.87$, which indicates that student-teachers are well aware that observation reinforces data collection skill in Action Research due to the fact that Action Research studies are basically dependent on observing a specific phenomenon or problem.

Table 5. Means and SD connected to action research data analysis skill

\begin{tabular}{cccc}
\hline \multicolumn{1}{l}{ Item No. } & Item & Mean & SD \\
\hline .27 & When analyzing data, the researcher focuses on: & 2.404 & 1.135 \\
.28 & Which one of the following reinforces data analysis and & 2.680 & 1.144 \\
& explanation skills: & 2.957 & .832 \\
.29 & Explaining data is: & 2.085 & .832
\end{tabular}

As can be seen in table (5), item (29) scored the highest, $\mu=2.95$, which points out that student-teachers realize that the purpose of explaining Action Research data is to reach the required meaning of explaining phenomena or resolving the problem under study.

One student mentioned: "in statistical analysis courses we learn how to carry out different calculations... however, we do not learn anything about data entry related to statistical software such as SPSS... most of us do not have the ability to read or explain software data outcomes... we only studied that theoretically".

Table 6. Means and SD connected to extracting actions research results skill

\begin{tabular}{|c|c|c|c|}
\hline Item No. & Item & Mean & $S D$ \\
\hline .31 & Qualitative results in Action Research are represented by: & 2.404 & .851 \\
\hline .32 & Action Research results cannot be generalized due to: & 2.680 & .980 \\
\hline .33 & When applying the results of an action research, one must focus on: & 2.702 & 1.196 \\
\hline
\end{tabular}


Table (6) indicates that item (33) scored the highest mean, $\mu=2.70$, which confirms that the ultimate purpose of conducting Action research Studies is to induce the required change.

One student stated: "Educational Statistics courses should have prerequisites which are all study courses... it should be taken in students' fourth year at the university".

\subsection{Results and Discussion Related to the Second Question}

Is there a statistically significant relationship, $(\alpha=.05)$ between the student/teachers' level of Action Research skills knowledge and their accumulated average in their major (specialization) at the Hashemite University?

Table 7. Pearson Correlatio

\begin{tabular}{|c|c|c|c|c|c|c|c|c|}
\hline \multicolumn{9}{|c|}{ Correlations } \\
\hline Results & Analysis & collection & hypothesis & problem & knowledge & $\begin{array}{c}\text { Major AA } \\
\text { Accumulative Average }\end{array}$ & & \\
\hline-.181 & -.286 & -.125 & .185 & -.147 & $.368^{*}$ & 1 & $\begin{array}{c}\text { Pearson } \\
\text { Correlation }\end{array}$ & \multirow{3}{*}{ GPA } \\
\hline .224 & .052 & .404 & 213 & .323 & .011 & & Sig. (2-tailed) & \\
\hline 47 & 47 & 47 & 47 & 47 & 47 & 47 & $\mathrm{~N}$ & \\
\hline-.061 & .131 & $.486^{*}$ & $.356^{*}$ & -.218 & 1 & $.368^{*}$ & $\begin{array}{l}\text { Pearson } \\
\text { Correlation }\end{array}$ & \multirow{3}{*}{ knowledge } \\
\hline .686 & .379 & .001 & .014 & .142 & & .011 & Sig. (2-tailed) & \\
\hline 47 & 47 & 47 & 47 & 47 & 47 & 47 & $\mathrm{~N}$ & \\
\hline .071 & $-.321-^{*}$ & .189 & $-.029-$ & 1 & $-.218-$ & $-.147-$ & $\begin{array}{l}\text { Pearson } \\
\text { Correlation }\end{array}$ & \multirow{3}{*}{ problem } \\
\hline .633 & .028 & .203 & .845 & & .142 & .323 & Sig. (2-tailed) & \\
\hline 47 & 47 & 47 & 47 & 47 & 47 & 47 & $\mathrm{~N}$ & \\
\hline-.041 & $-.127-$ & .080 & 1 & $-.029-$ & $.356^{*}$ & .185 & $\begin{array}{l}\text { Pearson } \\
\text { Correlation }\end{array}$ & \multirow{3}{*}{ hypothesis } \\
\hline .786 & .394 & .593 & & .845 & .014 & .213 & Sig. (2-tailed) & \\
\hline 47 & 47 & 47 & 47 & 47 & 47 & 47 & $\mathrm{~N}$ & \\
\hline $.290^{*}$ & .106 & 1 & .080 & .189 & $.486^{* *}$ & $-.125-$ & $\begin{array}{l}\text { Pearson } \\
\text { Correlation }\end{array}$ & \multirow{3}{*}{ collection } \\
\hline .048 & .477 & & .593 & .203 & .001 & .404 & Sig. (2-tailed) & \\
\hline 47 & 47 & 47 & 47 & 47 & 47 & 47 & $\mathrm{~N}$ & \\
\hline .209 & 1 & .106 & $-.127-$ & $-.321-^{*}$ & .131 & $-.286-$ & $\begin{array}{c}\text { Pearson } \\
\text { Correlation }\end{array}$ & \multirow{3}{*}{ analysis } \\
\hline .159 & & .477 & .394 & .028 & .379 & .052 & Sig. (2-tailed) & \\
\hline 47 & 47 & 47 & 47 & 47 & 47 & 47 & $\mathrm{~N}$ & \\
\hline \multirow[t]{2}{*}{1} & .209 & $.290^{*}$ & $-.041-$ & .071 & -.061- & -.181- & $\begin{array}{l}\text { Pearson } \\
\text { Correlation }\end{array}$ & \multirow{3}{*}{ results } \\
\hline & .159 & .048 & .786 & .633 & .686 & .224 & Sig. (2-tailed) & \\
\hline 47 & 47 & 47 & 47 & 47 & 47 & 47 & $\mathrm{~N}$ & \\
\hline
\end{tabular}

*. Correlation is significant at the 0.05 level (2-tailed).

**. Correlation is significant at the 0.01 level (2-tailed).

To answer the second question, Pearson Correlation Equivalent was calculated. Table (7) indicates that there is no statistical significance, $\alpha=.05$, between teachers' level of Action Research knowledge and their accumulated average at the Hashemite University which reinforces the results of the first question stating that: on the one hand, students are well informed theoretically about Action Research, but they are in great need for practical application. On the other hand, Statistics as an obligatory course is considered when calculating the accumulated average which, in turns, explains the appearance of such results. However, the analysis of the data for questions one and two show 
that the focus on action research is only theoretically appropriate. In other words, it seems that students receive good theoretical education on the importance of action research and on its methodology and use but they seem not to have received the same focus or training on the actual process of implementing action research or trying it during their Field Practice experience.

\section{Recommendations}

The researcher, upon reflecting on this research results, finds that some important aspects need be taken into consideration in preparing student-teachers. These aspects are mainly related to professionally preparing student-teachers in doing action research. Therefore, the researcher recommends that Statistical Analysis course description should include both the theoretical and the practical aspects, and the number of students enrolled in each section should not exceed 20. Furthermore, Students should be encouraged to conduct Action Research studies in the form of graduation projects in addition to practical education requirements. It is also recommended that Action Research is kept as one of the graduation requirements in practical education courses as the Faculty of Educational Sciences. The intention to remove this course from the graduation package requirement is not a very well-studied plan.

\section{References}

Abu Numra, K (2002). Students' Attitudes Towards practical Education Programs In Faculties of Educational Sciences Affiliated with UNRWA. Irbid Research and Studies, 5(2), 125-161.

Abu Numra, K (2005). A study entitled, Evaluating Practical Education Programs in Faculties of Educational sciences at Jordan's Private Universities from the Perspective of students/teachers. Mutah Research and Studies, 20(2), 109-148.

Bakheet, M (2009). Designing a Training Program and Exploring its Effect on Action Research Skills Development in Social Studies Teachers. Unpublished Doctoral Dissertation, Yarmouk University

Brookes, V. \& Sikes, P. (1997). The Good Mentor Guide, Initial Teacher Education in Secondary Schools. Open university Press, Buckingham. Philadelphia

Faculty of Educational Sciences, (2006). Practical Education Guide, Faculty of Educational Sciences, Hashemite University, Az'zarqa, Jordan.

Haider, H (2004). Action Research between Thinking about Professional Practice and improving it, Dubai, Dar Al Qalam.

Khawaldeh, N (2003). student/teacher degree of practice of instructional efficiencies necessary for teaching Islamic educations subjects in primary schools through practical education programs. Mutah Research and Studies, 18(1), 91-117.

Ministry of Education, (2006). The Final Draft of Teacher Professional Development standards, The National Standards Conference for Teacher's Professional Development. Amman, Jordan.

Nasser, I (2018). The state of Education in the Arab World. Arab Center. Washington DC.

O'Connor, R. Et el (2006). Action Research, A Tool for Improving Teacher Quality and Classroom Practice. Available at https,// www.Researchgate.net.

Schon, D. (1983). The Reflective Practitioner., Basic Books, Inc., New York.

Shatat, Y (1995). Educational Research, Its Importance for Teacher and School and how to Prepare for it, UAE, Journal of Education, 126-128.

Sheikh, O (1998). Bridging Educational Research and Educational Decisions, a work paper presented at the Arab World Educational Research Conference, Towards Where? Amman, Jordan.

Shmeider, A. (1973). Competency-based Education, The State of Scene. American Association of Colleges for Teacher Education.

Squires, G. (1999). Teaching as a Professional Discipline. London, Falmer Press

The Hashemite University. (2006). Field Training Regulation, Faculty of Education. Hashemite University. Az'zarqa, Jordan.

Zaitoun, A \& Obaidat,S (1984). Analytical Evaluative Study for the Practical Education Program at the University of Jordan. Studies, University of Jordan, 11(6), 157-175. 